\title{
Solusi Menuju Konvergensi Arah Komunikasi Kebijakan Publik dalam Rangka Antisipasi Krisis Energi
}

\author{
Yanuar Luqman, Sumardjo, Sarwititi Sarwoprasodjo dan Armansyah H. Tambunan \\ Program Studi Ilmu Komunikasi, FISIP, Universitas Diponegoro, Semarang, Jl. Prof Soedharto SH, \\ Tembalang, Semarang Telp +62 247465408 \\ Email : yanuar@undip.ac.id
}

\begin{abstract}
The study is focusing on examining an energy crisis from the perspective of organizational communication of public policy. Based on the Theory of Sensemaking (Weick, 1995), the construction of public policy communication is explored to anticipate the forthcoming of energy crises. Success or failure of the policy is heavily influenced by the construction of communication in the process of making energy crisis anticipation policy that involving many parties. From a constructivist perspective, and employing the phenomenological technique of communication experience of policy makers, it is implied that the energy crisis is interpreted in a diverse but refers only as an economic problem to the exclusion of environmental issues. The problem statement is not the same because of that sensemaking policy is not optimal. It needs a more independent and hybrid institution as a solution of public policy communication regarding the anticipation of energy crises.
\end{abstract}

Keywords: energy crises, constructions, sensemaking

\begin{abstract}
Abstrak
Penelitian ini berfokus pada kajian krisis energi dari perspektif komunikasi organisasi kebijakan publik. Berdasarkan Teori Sensemaking (Weick, 1995), konastruksi komunikasi kebijakan publik dieksplorasi untuk mengantisipasi krisis energi yang akan datang. Keberhasilan atau kegagalan kebijakan tersebut sangat dipengaruhi oleh konstruksi komunikasi dalam proses pembuatan kebijakan antisipasi krisis energi yang melibatkan banyak pihak. Dari perspektif konstruktivis, dan menggunakan teknik fenomenologis pengalaman komunikasi para pembuat kebijakan, disiratkan bahwa krisis energi ditafsirkan secara beragam namun terbatas mengacu pada masalah ekonomi dengan mengesampingkan isu lingkungan. Problem statement tidak sama karena sensemaking kebijakan itu tidak optimal. Diperlukan lembaga yang lebih mandiri dan hybrid sebagai solusi komunikasi kebijakan publik mengenai antisipasi krisis energi.
\end{abstract}

Kata Kunci: krisis energi, konstruksi, sensemaking

\section{Pendahuluan}

Krisis energi telah terjadi, hal ini disebabkan oleh pemakaian energi dunia meningkat pesat. Pada tanggal 5 Maret 2015, Harian Kompas memaparkan tentang krisis energi yang melanda Indonesia. Data menunjukkan bahwa cadangan minyak Indonesia sekitar 3,7 milyar barrel dengan produksi bahan bakar minyak (BBM) dalam negeri saat ini rata-rata 800 ribu barrel per hari 
sehingga diperkirakan akan habis dalam 11 tahun mendatang. Eksplorasi cadangan minyak baru semakin sulit apalagi dengan kondisi harga minyak yang rendah sehingga investasi menjadi tidak ekonomis. Pemerintah dalam hal ini yang berperan sebagai regulator membuat kebijakan dalam upaya antisipasi terjadinya krisis energi.

Dalam upaya antisipasi terjadinya krisis energi, pemerintah telah membuat beberapa kebijakan. Untuk mendapatkan hasil yang maksimal atas kebijakan dalam upaya antisipasi terjadinya krisis energi perlu adanya proses komunikasi yang komprehensif. Kebijakan dalam upaya antisipasi terjadinya krisis energi yang belum berjalan optimal. Terdapat beberapa faktor yang dapat menyebabkan kebijakan dalam upaya antisipasi terjadinya krisis energi belum optimal. Kemungkinan salah satu faktor penyebab ke-tidak optimal kebijakan dalam upaya antisipasi terjadinya krisis energi adalah faktor komunikasi.

Terdapat beberapa kemungkinan antara lain komunikasi kebijakan dalam upaya antisipasi terjadinya krisis energi ada namun belum efektif. Kemungkinan lain, pada proses pembuatan kebijakan dalam upaya antisipasi terjadinya krisis energi tidak didasarkan dengan komunikasi organisasi yang baik atau setelah kebijakan dalam upaya antisipasi terjadinya krisis energi tersebut tersusun tidak di-komunikasikan dengan baik. Komunikasi organisasi menjadi kunci dalam proses konstruksi kebijakan publik upaya antisipasi terjadinya krisis energi.

Pemerintah beserta masyarakat hendaknya melakukan terobosan yang nyata, sistematis dan terstruktur dalam usaha penghematan energi maupun mengembangkan energi yang berasal dari non-fosil sebagai langkah antisipasi terjadinya krisis energi. Jalan keluar untuk mengatasi krisis energi adalah dengan melakukan penghematan dan mengembangkan energi terbarukan (ET). ET menurut Peraturan Pemerintah Republik Indonesia Nomor 79 Tahun 2014 tentang Kebijakan Energi Nasional adalah energi yang dihasilkan dari sumberdaya energi yang berkelanjutan, seperti panas bumi, angin, bioenergi, sinar matahari, aliran dan terjunan air serta gerakan dan perbedaan suhu lapisan laut. Menurut Keraf (Kompas, Selasa 24 Mei 2015), pengembangan ET dapat membangkitkan kemandirian bangsa dengan melibatkan lebih banyak masyarakat dalam produksi. Misalnya untuk memproduksi biofuel dan biomass dapat melibatkan banyak petani untuk menanam sumber energi.

Isu lingkungan tentang pemanasan global (global warming) akibat pembakaran bahan bakar fosil mestinya memberikan pengaruh yang besar kepada kebijakan energi di tiap tiap negara. Telah dilakukan berbagai pembicaraan secara internasional untuk menemukan cara menekan emisi karbon. Pertumbuhan penduduk cenderung tinggi membawa konsekuensi pertumbuhan atau mempertahankan ekonomi. Konsekuensi lanjutan dari pertumbuhan tersebut dibutuhkan konsumsi sumberdaya dan energi dalam jumlah besar, yang akibatnya akan muncul rangkaian sebab akibat berupa memburuknya lingkungan. Saat ini sepertinya belum ada kebijakan untuk mengatasi persoalan energi yang berkaitan erat antara pertumbuhan ekonomi, sumberdaya energi dengan masalah lingkungan,.

Secara nasional, terdapat 4 permasalahan pokok dalam pemanfaatan energi secara nasional. Pertama, 90 persen energi nasional masih didominasi energi fosil, kondisi yang sangat riskan mengingat keterterbatasan cadangan. Kedua, kondisi geografis Indonesia menyulitkan distribusi energi. Ketiga, eksploitasi energi fosil yang sangat ekstensif dapat menimbulkan kerusakan lingkungan yang berat. Keempat, ketergantungan eksplorasi dan eksploitasi energi pada negara asing (Rezavidi, 2012).

Pada sisi komunikasi, ketidakpastian (uncertainty) adalah komponen dari krisis, dan terutama terjadi ketika isu-isu (misalnya berkaitan dengan energi) bersifat teknis, tidak mudah dijelaskan dan masih kurang dapat menerima solusi yang jelas. Para pembuat keputusan jarang memahami penyebab berkurang ketersediaan energi atau kenaikan harga pasokan energi, juga tidak memahami apa yang harus dilakukan untuk 
mengatasinya.

Istilah krisis energi, adalah simbol linguistik, metafora. Terbatas ketika masalah sosial cukup parah untuk membuat khalayak publik menerima penggambaran sebagai krisis itu dapat diharapkan memiliki dampak yang signifikan pada proses pembuatan kebijakan. Dalam memahami krisis diperlukan peristiwa pencetus (shock) menangkap perhatian publik dan masalah yang mendasari selanjutnya dapat digambarkan sebagai keadaan yang parah.

Grossman dalam artikel Energy shocks, crises and the policy process: A review of theory and application yang dimuat dalam jurnal Energy Policy 77 (2015) 56-69 mencoba mendefinisikan krisis dari berbagai perspektif. Grossman mengutip Garrison (1981, 315) bahwa krisis sebagai "titik balik akut yang biasanya melibatkan beberapa gangguan atau kelainan. Coyne (2011), mendefinisikan krisis sebagai "sebuah peristiwa tak terduga yang menciptakan ketidakpastian dan menimbulkan ancaman langsung tujuan dan norma-norma organisasi atau masyarakat. Perspektif Marxis (Offe : 1976, 31) menjelaskan krisis sebagai proses dimana struktur sistem dipertanyakan, Nohrstedt dan Weible $(2010,3)$ berpendapat bahwa, krisis menunjukkan periode gangguan yang bersamaan dengan pertanyaan yang meluas atau mendiskreditkan kebijakan yang ditetapkan, praktik dan institusi.

Krisismemilikitigakarakteristik:kejutan, ketidaknyamanan dan urgensi. Karakter urgensi merujuk pada waktu kompresi, kekhawatiran bahwa ancaman nyata dan harus ditangani secepatnya. Urgensi tidak berarti bahwa semua krisis sebagai kejutan besar bagi masyarakat. Krisis dapat terjadi krisis berlarut-larut yang membutuhkan waktu untuk berkembang ke arah yang buruk sebagai akibat dengan akumulasi kondisi. Namun, akumulasi ini dapat menjadi krisis ketika mereka menimbulkan perasaan darurat yang harus diatasi.

Diperlukan solusi komunikasi yang memadai karena kebijakan publik tentang energi, merupakan kebijakan yang menyangkut langsung kebutuhan dasar masyarakat. Isu krisis energi dimulai dari peningkatan aktivitas manusia secara signifikan meningkatkan pula kebutuhan atas sumber daya pendukung. Selama ini kebutuhan energi dibangkitkan dengan menggunakan energi yang berasal dari fosil. Sifat energi fosil yang tidak dapat diperbaharui dan terbatas menjadi masalah besar dan potensial menimbulkan krisis energi. Hampir semua energi yang dipakai berasal bahan bakar fosil berupa batubara, minyak dan gas alam, selebihnya adalah non fosil. Krisis terjadi karena adanya peningkatan konsumsi energi yang tidak diimbangi oleh produksi energi yang mencukupi.

Komunikasi dalam menyusun kebijakan publik yang tepat pada sasaran diperlukan untuk mendapatkan respon baik dan dukungan dari masyarakat. Komunikasi organisasi diperlukan oleh pembuat kebijakan untuk merespon/ meng-interpretasi lingkungan dan bagaimana mengelola persepsi dalam rangka membentuk kebijakan yang dipilih. Peran masyarakat merupakan faktor penting dalam formulasi dan implementasi kebijakan publik. Selain menjadi dasar rujukan, pemahaman masyarakat juga menjadi kekuatan yang besar untuk mendukung implementasi dari sebuah kebijakan.

Dalam usaha antisipasi krisis energi, komunikasi menjadi faktor penting sebagai alat untuk melakukan sosialisasi, deseminasi atau difusi. Sebelum dilakukan sosialisasi deseminasi atau difusi kepada masyarakat, perlu dilakukan pembahasan tentang bagaimana kebijakan dibuat dan dirancang untukmasyarakatluas. Komunikasi organisasi yang terjadi di lingkungan pembuat antisipasi krisis energi menarik untuk diteliti. Pengetahuan dan pengalaman mempengaruhi antisipasi krisis energi dalam melakukan proses komunikasi kebijakan publik antisipasi krisis energi. Tujuan dari penelitian ini adalah untuk menganalisis komunikasi organisasi dalam formulasi dan implementasi kebijakan publik menghadapi krisis energi.

Terdapat

kebijakan-kebijakan pemerintah yang perlu dikaji latar belakang komunikasi organisasinya dalam pembuatan 
kebijakan antisipasi krisis energi. Kebijakan tersebut antara lain adalah Perpres Nomor 22 Tahun 2017 Tentang Rencana Umum Energi Nasional, Perpres No 41 Tahun 2016 Tentang Tata Cara Penetapan dan Penanggulangan Krisis Energi dan Darurat Energi (Krisdaren), PP No 79 Tahun 2014 Tentang Kebijakan Energi Nasional, Undang-Undang Nomor 30 Tahun 2007 Tentang Energi serta RPJM 2015-2019 dipaparkan tentang upaya untuk mengatasi kemungkinan krisis energi yang disusun oleh Kementerian PPN/ Bappenas.

Tema besar penelitian ini adalah komunikasi pembangunan yang didalamnya membahas masalah pemanfaatan alam dan lingkungan hidup. Untuk mengatasi kerusakan lingkungan yang diakibatkan oleh pembangunan diperlukan inovasi yang dapat digunakan (diadopsi) untuk kepentingan masyarakat (Rogers, 2003: 229-258). Paradigma pembangunan berubah dengan memperhatikan aspek berkelanjutan. Dengan memperhitungkan karakteristik spesifik pembangunan berkelanjutan memiliki implikasi besar bagi proses komunikasi diterapkan untuk memfasilitasi inisiatif pembangunan tersebut. Komunikasi pembangunan tidak dapat lagi mengandalkan pendekatan monologic. Pembangunan yang berkaitan dengan sektor lingkungan dan energi menggunakan perspektif pembangunan berkelanjutan ditujukan pada komunikasi dialogis, yang didasarkan pada pendekatan partisipatif interaktif (Quarry dan Ramirez ,2009).

Penelitian ini mencoba untuk menganalisis komunikasi organisasi pembuat kebijakan yang terjadi dalam perumusan kebijakan publik antisipasi krisis energi. Penelitian konstruksi komunikasi kebijakan publik antisipasi krisis energi menggunakan landasan paradigma interpretif yang mana lebih memfokuskan pada proses organisasi daripada stabilitas organisasi (Trujillo \& Toth, 1987: 199-231). Asumsinya bahwa tindakan sosial tidak dapat diamati, tetapi lebih diarahkan pada pemaknaan subjektif terhadap tindakan sosial
(Neuman, 2006: 83; Sarantakos, 1993 : 37).

Pengolahan informasi organisasi sering dianggap sebagai konsep pengorganisasian untuk memahami berbagai fenomena dan saling terkait yang signifikan dalam pengambilan keputusan organisasi, perumusan strategi dan implementasi strategi. Organizational Information Process Theory digunakan untuk menjelaskan perilaku organisasi dengan melihat arus informasi yang terjadi di dalam dan sekitar organisasi. (Jablin \& Putman, 2001 : 203). Dalam menyusun kebijakan pengembangan beserta program komunikasi tentang antisipasi krisis energi, diperlukan diskusi dalam konteks komunikasi dalam organisasi. Penelitian ini menelaah komunikasi organisasi yang terjadi dalam institusi/ lembaga yang membuat kebijakan dan program komunikasi tentang antisipasi krisis energi.

Proses komunikasi organisasi dalam pengambilan keputusan Weick menggunakan teori sensemaking, dimana anggota organisasi memahami peristiwa organisasi dengan meekstraksi isyarat untuk membuat penjelasan yang masuk akal (Weick, 1995 : 61-62). Dalam sensemaking terdapat tujuh sifat:

1. Grounded in identity construction, identitas adalah pertanyaan tentang siapa yang menunjukkan bagaimana dan apa yang subjek pikir.

2. Retrospective, dalam membuat keputusan perlu proses refleksi. Retrospeksi untuk mempelajari dengan melihat kembali apa yang subjek lakukan sebelumnya.

3. Enactive of sensible environments, dalam kehidupan organisasi sering menghasilkan bagian dari lingkungan yang mereka hadapi. Entitas dan lingkungan merupakan faktor yang saling mempengaruhi.

4. Social, sensemaking adalah proses sosial; pemikiran manusia dan fungsi sosial merupakan aspek penting dari yang lain. Apa yang dilakukan seseorang tergantung pada orang lain.

5. Ongoing, sensemaking tidak ada batasan 
mulai atau berhenti, itu adalah proses yang berkelanjutan.

6. Focused on and by extracted cues, kepentingan dan ketidak-sadaran seseorang tergantung apa isyarat yang menjadi fokus.

7. Driven by plausibility rather than accuracy, ketika menemukan jawaban atas pertanyaan, subjek akan berhenti mencari.

Pembahasan antisipasi krisis energi erat kaitannya dengan proses adopsi-inovasi. Menurut Seligman dalam European Journal of Innovation Management Vol. 9 No. 1, 2006 pp. 108-120 yang berjudul Sensemaking throughout adoption and the innovation-decision process menyimpulkan terdapat faktor yang mempengaruhi adopsi, harus dipahami adopsi sebagai suatu proses, dan untuk mengeksplorasi subproses yang mempengaruhi persepsi dan sikap. Deskripsi Weick tentang sensemaking sebagai model adopter berpusat pada proses perilaku yang berkaitan dengan adopsi teknologi..

Penelitian ini menggunakan pendekatan subjektivist dengan pilihan metode fenomenologi.Pendekatan subjectivist usaha memahami proses melalui pengalaman langsung pembuatan keputusan antisipasi krisis energi, memahami (understanding, verstehen) guna mengungkap komunikasi organisasi dalam formulasi dan implementasi kebijakan publik menghadapi krisis energi. Disamping itu, dengan pendekatan dan metode tersebut dapat digunakan untuk membuat rumusan alternatif strategi komunikasi untuk perumusan formulasi implementasi kebijakan publik antisipasi krisis energi.

\section{Metode Penelitian}

Penelitian ini menggunakan metode kualitatif dengan menggunakan pendekatan fenomenologi. Individu-individu dari lembaga pembuat kebijakan mengenai antisipasi krisis energi menjadi subjek penelitian ini. Fenomenologi berfokus pada pengalaman sadar manusia; suatu usaha memahami proses (process knowing) melalui pengalaman langsung (Littlejohn, 2005 : 38). Secara operasional, penelitian ini dilakukan untuk data yang bersifat emic (how people think) dengan memahami pengalaman pelaku pembuat keputusan mengenai antisipasi krisis. Menurut Orbe dalam Littlejohn \& Foss, ed, (2009: 749-751) fenomenologi adalah studi tentang esensi, atau pengalaman hidup seseorang di dunia hidupnya sebelum ini akan dikategorikan atau berteori.

Unit of analysis dari penelitian ini adalah individu-individu pembuat keputusan komunikasi kebijakan publik antisipasi krisis energi. Dewan Energi Nasional (DEN) adalah salah satu unit analisis penelitian ini. Penelitian ini juga dilaksanakan untuk mendapatkan data dalam tataran kelembagaan. Pada tataran kelembagaan, studi ini berusaha mendapatkan data dari Kementerian Energi Sumber Daya Mineral (ESDM) khususnya Direktorat Energi Baru Terbarukan dan Konservasi Energi (EBTKE), Badan Perencanaan Pembangunan Nasional (Bappenas) serta para stakeholder yang berkaitan dengan kebijakan antisipasi krisis energi seperti Kementerian Pertanian dan Kementerian Kehutanan dan Lingkungan Hidup. Penelitian ini digali berdasarkan data yang diperoleh mengenai pengalaman komunikasi organisasi dalam antisipasi krisis energi. Data dalam penelitian dengan pendekatan fenomenologi didapatkan dengan melakukan wawancara mendalam (indepth interview). Wawancara mendalam mencakup model terfokus atau semi terstruktur (Minichiello, 1995: 62). Pengambilan data menggunakan alat bantu yaitu interview guide.

Penelitian ini adalah penelitian kualitatif dengan pilihan analisis fenomenologi yang dikemukakan oleh von Eckartsberg yang dikutip oleh Moustakas (1994 : 15-16). Langkah-langkah analisis dalam fenomenologi yang pertama, the problem and question formulation, dalam langkah ini, dideskripsikan fokus penelitian dengan pertanyaan agar dapat dimengerti orang lain. Dalam konteks penelitian ini, adalah bagaimana pengalaman subjek atas interpretasi terhadap 
komunikasi organisasi mengenai antisipasi krisis energi. Kedua, the data generating situation : the protocol life text, langkah ini dilakukan pembuatan narasi yang bersifat deskriptif berdasarkan atas dialog (wawancara) mengenai antisipasi krisis energi. Ketiga, the data analysis: explication and interpretation, setelah data terkumpul, perlu dibaca dan diteliti dengan cermat hasil wawancara untuk mengungkapkan konfigurasi makna, struktur makna, maupun bagaimana makna tersebut diciptakan.

$\begin{array}{crr}\text { Menurut Kaam dan } & \text { Stevick } \\ \text { dalam } & \text { Moustakas } \quad(1994: 181: 182) & \text { dalam }\end{array}$
pengorganisasian, analisis dan sintesis data serta pada bagian ringkasan, implikasi dah hasilnya terdapat langkah-langkas sebagai berikut : Pertama, organizing, analyzing and synthetizing data, dikembangkan deskripsi tektural dan struktural individu berdasar atas hasil wawancara yang dilakukan. Langkah selanjutnya adalah menggabungkan antara deskripsi tektural dan struktural individu menjadi satu kesatuan. Sebagai langkah terakhir, dilakukan pembuatan sintesis makna tektural dan struktural untuk memperoleh esensi pengalaman komunikasi organisasi mengenai antisipasi krisis energi. Kedua, Summary, implication and outcomes, dalam penelitian fenomenologi langkah terakhirnya adalah membuat ringkasan, membuat implikasi dari penelitian yang dilakukan berdasarka temuan dilapangan. Sebagai penutup perlu disusun komentar yang berkaitan dengan pelaksanaan dan tujuan penelitian dimasa datang.

\section{Hasil dan Pembahasan}

\section{Komunikasi organisasi: Formulasi dan Implementasi Kebijakan Krisis Energi}

Fakta yang berdasar data dan informasi, terdapat ancaman terjadinya krisis energi, sehingga perlu kebijakan tentang ET biomassa, dengan pendekatan sensemaking dipakai untuk menjawab pertanyaan mengenai bagaimana komunikasi berperan dalam penyusunan kebijakan dalam konteks komunikasi organisasi menghadapi ancaman krisis energi.

Krisis energi dan permasalahan lingkungan hidup dalam riset ini adalah awalan dalam membahas pengembangan energi baru terbarukan. Memahami proses formulasi dan implementasikebijakanpublikdalammenghadapi krisis energi dilakukan dengan memahami komunikasi organisasi yang dilaksanakan. Komunikasi organisasi yang dilakukan dalam rangka formulasi dan implementasi kebijakan publik tersebut dilihat dari (1) Makna dan data krisis energi, (2) Kebijakan dan komunikasi Organisasi dalam Pembahasan Krisis Energi, dan (3) Pertimbangan dalam membuat kebijakan.

\section{Makna dan Data Krisis Energi}

Pemahaman atas makna dan data krisis energi yang beragam tentang krisis energi jika dirujuk dengan teori Organization Information Process (Jablin \& Putman, 2001) bahwa interpretasi mempengaruhi transformasi data tentang krisis energi menjadi informasi yang dapat dipahami. Interpretasi indvidu informan atas data ketersediaan energi, situasi ekonomi dan potensi energi lain untuk antisipasi krisis energi kemudian dapat mempengaruhi perspektif atas krisis energi.

Krisis energi dalam pemahaman informan dibangun dari proses mencermati data. Setidaknya terdapat perpektif pemahaman krisis energi. Pertama, krisis energi dimaknai terjadi karena tidak seimbangnya supply dan demand. Kedua, krisis energi tidak akan terjadi apabila negara sudah tidak mampu lagi membeli energi. Artinya selama negara dan masyarakat dapat membeli energi dengan harga berapapun maka krisis energi tidak akan terjadi. Ketiga, krisis dimaknai sebagai sesuatu yang unlikely happen sepanjang Indonesia mampu menyediakan energi dan mengembangkan energi non fosil. Yang terakhir, krisis energi dimaknai terbatas krisis listrik, listrik yang ada sekarang dalam keadaan tidak merata karena ketimpangan infrastruktur penyedia.

Pendekatan sensemaking yang dikemukakan oleh Wieck (1995) mengenai pemahaman atas krisis energi yang dilengkapi oleh data menunjukkan bagaimana stakeholder berfikir 
dan mengolah data. Perpektif yang beragam atas krisis energi didasarkan pada konstruksi identitas (grounded in identity construction) serta difokuskan pada dan oleh isyarat yang diekstraksi (focused on and by extracted cues). Pada akhirnya dalam membuat keputusan diperlukan proses retrospective dimana dalam membuat keputusan perlu proses refleksi.

Berdasar temuan, krisis energi dimaknai secara beragam. Grounded in identity construction mengenai krisis energi, hal ini berkaitan dengan subjek (sensemaker) dan subjektifitas (cara pandang). Identitas adalah unsur pembeda dalam melakukan sensemaking. Deskripsi struktural dari masing-masing individu informan menunjukkan identitas yang ditunjukkan oleh temuan bagaimana dan apa yang dipikirkan seperti tersebut di atas. Aspek Retrospective dalam membuat keputusan perlu proses refleksi. Melihat kembali proses yang pernah dilalui. Pada aspek ini, melihat pengalaman sebuah proses, tergantung pada kesuksesan sebuah proses. Menurut Starbuck \& Milliken (1988), retrospeksi membuat masa lalu lebih jelas daripada sekarang atau masa depan. Dalam konteks pengalaman individu, makna atas krisis dipengaruhi oleh pengalaman masa lalu dalam membicarakan masalah krisis energi di Indonesia. Istilah unlikely happend misalnya, adalah gambaran proses restrospeksi yang berdasarkan pengalaman informan dalam menyusun perencanaan pembangunan di Indonesia.

Sensemaking memiliki aspek focused on and by extracted cues, yang mana pengambil keputusan dihadapkan dengan banyak isyarat. Seseorang hanya akan melihat beberapa isyarat, karena terdapat mekanisme filter. Kepentingan dan ketidak-sadaran seseorang tergantung apa isyarat yang menjadi fokus. Makna krisis energi tentunya tergantung pada isyarat dalam bentuk data yang kemudian menjadi mekanisme filter untuk kemudian dapat mempengaruhi seseorang untuk memaknai krisis energi.

Permasalahan energi tidak lepas dari permasalahan lingkungan hidup. Dari hasil wawancara mendalam yang dilakukan, tersirat bahwa krisis energi terbatas dilihat dari aspek ekonomi. Aspek lingkungan hidup dalam hal ini adalah berkaitan dengan efek penggunaan energi fosil yang tidak ramah lingkungan. Mempunyai eksploitasi energi fosil yang sangat ekstensif dapat menimbulkan kerusakan lingkungan yang berat (Rezavidi, 2012). Sebagai contoh penggunaan energi fosil adalah pemakaian batubara sebagai bahan bakar yang besar, menyebabkan polusi udara menjadi masalah yang berat. Pembakaran batubara meninggalkan jejak kerusakan, polutan beracun mengancam kesehatan masyarakat dan lingkungan sekitar. Pembakaran batubara adalah sumber utama gas rumah kaca penyebab perubahan iklim seperti karbon dioksida, sulfur dioksida, nitrogen dioksida, dan metana yang memperburuk kondisi iklim.

Jika ditarik pada ranah global, isu lingkungan tentang pemanasan global (global warming) akibat pembakaran bahan bakar fosil memberikan pengaruh yang besar kepada kebijakan energi di tiap tiap negara. Telah dilakukan berbagai pembicaraan secara internasional untuk menemukan cara menekan emisi karbon. Pertumbuhan penduduk yang cenderung tinggi membawa konsekuensi pertumbuhan atau mempertahankan ekonomi. Konsekuensi lanjutan dari pertumbuhan tersebut dibutuhkan konsumsi sumberdaya dan energi dalam jumlah besar, yang akibatnya akan muncul rangkaian sebab akibat berupa memburuknya lingkungan. Hubungan erat antara pertumbuhan ekonomi, sumberdaya energi dengan masalah lingkungan, saat ini sepertinya belum ada kebijakan untuk mengatasi permasalahan pembangunan yang berbasis lingkungan hidup.

\section{Kebijakan dan Komunikasi Organisasi dalam Pembahasan Krisis Energi \\ Organization Information Process}

Theory (Jablin \& Putman, 2001) digunakan untuk menjelaskan perilaku organisasi dengan melihat arus informasi yang terjadi di dalam dan sekitar organisasi. Komunikasi dalam membuat kebijakan publik menghadapi krisis 
energi antara lain adalah Rencana Umum Energi Nasional (RUEN) yang di dalamnya terdapat rumusan Krisis Energi dan/atau Darurat Energi (Krisdaren). Program mandatory Bahan Bakar Nabati 20 menjadi bahasan dalam upaya menghadapi krisis energi. Ancaman krisis energi, menurut informan menjadi variabel yang dipakai dalam menyusun Rencana Pembangunan Jangka Menengah (RPJM).

Komunikasi organisasi yang terjadi dilakukan dengan pemaparan informasi, kesiapan untuk menghadapi berbagai elemen lingkungan, dan pengembangan strategi dan sistem sensorik untuk menghadapi krisis energi. Komunikasi dengan penyimpanan informasi dan mekanisme transmisi informasi tentang krisis energi. Arus informasi yang terjadi bermuara pada DEN dengan rumusan Krisdaren disamping RPJM. Krisdaren disusun berdasarkan diskusi dalam forum DEN yang terdiri dari unsur pemerintah dan unsur pemangku kepentingan. Information processing model of choice dalam konteks krisis energi, organisasi harus melihat fenomena informasi yang sedang berkembang di kalangan para pemangku kepentingan. Fokus perhatian informan yang berbeda-beda dalam memaknai krisis energi disebabkan oleh struktur organisasi. Struktur organisasi dalam hal ini merupakan mekanisme untuk memfokuskan perhatian pada masalah krisis energi.

Krisis energi dibicarakan terus-menerus karena menjadi latar belakang pembuatan KEN yang melibatkan lintas sektoral, akademisi, produsen dan regulator. Kebijakan publik yang dibuat oleh pemerintah mengenai antisipasi krisis energi dibicarakan dalam forum Dewan Energi Nasional (DEN) yang terdiri dari unsur pemerintah dan unsur pemangku kepentingan serta para menteri terkait. Asosiasi/industri, pemerintah daerah, universitas/akademisi dan BUMN terkait juga menjadi pihak yang dilibatkan, dimintai pendapat dalam penyusunan kebijakan berkait dengan antisipasi krisis energi. Komunikasi menjadi sedikit lama karena perbedaan perspektif dalam forum tersebut. Komunikasi yang terjadi dalam membahas krisis terjadi ketidaklancaran karena rumusan problem statement yang tidak sama. Materi yang dibicarakan dalam konteks krisis energi berkisar mengenai upaya penghematan energi (konservasi) dan upaya pengembangan energi baru dan terbarukan (non fosil).

Kebijakan dan komunikasi organisasi dalam pembahasan krisis energi jika dilihat pada aspek enactive of sensible environments, social, grounded in identity construction, retrospective dan focused on and by extracted cues yang ada dalam teori Sensemaking. Pada aspek enactive of sensible environments, entitas dan lingkungan merupakan faktor yang saling mempengaruhi pola komunikasi. Inti dari aspek ini adalah enactment pada organisasi memiliki karakteristik kompleksitas dan perubahan lingkungan yang dipersepsikan manajemen secara kolektif. Setiap organisasi memiliki kompleksitas dan perubahan lingkungan yang berbeda-beda tergantung persepsi mereka terhadap ketidakpastian lingkungan.

Kebijakan publik yang dibuat oleh pemerintah mengenai antisipasi krisis energi dibicarakan dalam forum Dewan Energi Nasional (DEN) yang terdiri dari unsur pemerintah dan unsur pemangku kepentingan serta para menteri terkait. Asosiasi/industri, pemerintah daerah, universitas/akademisi dan BUMN terkait juga menjadi pihak yang dilibatkan, dimintai pendapat dalam penyusunan kebijakan berkait dengan antisipasi krisis energi. Komunikasi organisasi mengenai krisis energi jika dikaitkan enactment, digunakan untuk memahami proses pengorganisasian yang terjadi dalam menghadapi adanya perubahan lingkungan. Ancaman krisis energi merupakan perubahan lingkungan yang harus diantisipasi. Pembuatan/penetapan sebuah kebijakan berkaitan dengan krisis energi dipengaruhi oleh keadaan lingkungan yang didasarkan oleh data. Kompleksitas dan perubahan lingkungan berbeda-beda tergantung pada persepsi organisasi terhadap ketidakpastian lingkungan yang diakibatkan ancaman krisis.

Pada aspeks social, pihak eksternal dan internal pada masing-masing lembaga juga 
mempengaruhi komunikasi organisasi dalam pembahasan krisis energi. Masing-masing pihak baik eksternal maupun internal membawa identitas (grounded in identity construction) yang mempengaruhi pandangan yang berdasar pada data yang dipakai untuk melakukan pembahasan krisis energi. Komunikasi menjadi sedikit lama karena perbedaan perspektif dalam forum tersebut, dalam membahas krisis terjadi ketidaklancaran karena rumusan problem statement yang tidak sama. Lebih lanjut, aspek refleksi (retrospective)dan pemaknaan atas tanda (focused on and by extracted cues) juga mempengaruhi individu dalam sebuah lembaga dalam pembahasan krisis energi.

Materi yang dibicarakan dalam konteks krisis energi berkisar mengenai upaya penghematan energi (konservasi) dan upaya pengembangan energi baru dan terbarukan (non fosil). Pembahasan krisis energi erat kaitannya dengan proses adopsi-inovasi. Menurut Larry Seligman (2006), menyimpulkan bahwa terdapat faktor yang mempengaruhi adopsi, harus dipahami adopsi sebagai suatu proses, dan untuk mengeksplorasi subproses yang mempengaruhi persepsi dan sikap. Deskripsi Weick tentang sensemaking sebagai model adopter berpusat pada proses perilaku yang berkaitan dengan adopsi teknologi.

Sejalan dengan Weick, Rogers (2003) mengemukakan konsep adoptability yang dapat dikaitkan dengan pembahasan krisis energi. Adoptabilityakan dapattercapai apabilakebijakan penanggulangan krisis energi dapat menjadikan kondisi lebih baik daripada sebelumnya (relative advantage). Kebijakan harus sesuai (compatible) dengan mempertimbangkan nilai, keyakinan sosial budaya, ide diperkenalkan sebelumnya dan kebutuhan masyarakat atas inovasi dalam rangka penanggulangan krisis energi. Krisis energi adalah masalah yang rumit dan kompleks, oleh karena itu sebuah kebijakan harus diklasifikasi dalam kompleksitas - kesederhanaan sehingga pihak-iphak terkait dapat mengambil porsi sesuai dengan kemampuan. Kebijakan mengenai krisis energi akan mudah diadopsi jika dapat dicoba dengan mudah (trialibility) serta harus mudah diamati dan dikomunikasikan kepada orang lain (observabilty).

\section{Pertimbangan dalam Membuat Kebijakan}

Kebijakan-kebijakan yang dibuat dalam rangka antisipasi ancaman krisis energi tentunya didasari oleh beberapa pertimbangan. Pertimbangan yang utama menurut beberapa informan mengenai antisipasi ancaman krisis energi antara lain data mengenai impor BBM untuk konsumsi dalam negeri, Indonesia sekarang ini dalam sektor BBM sebagian besar berasal dari pembelian dari luar negeri (impor). Ketersediaan cadangan energi eksisting juga menjadi salah satu faktor pertimbangan dalam penyusun kebijakan, cadangan energi Indonesia merupakan indikator dari ketahanan energi. Krisis energi selain berkaitan erat dengan masalah lingkungan hidup juga menjadi masalah ekonomi. Perekonomian adalah salah satu faktor yang mempengaruhi penyusunan kebijakan. Masalah keseimbangan antara supply dan demand, pertumbuhan produksi energi tidak seimbang dengan pertumbuhan kebutuhan yang semakin meningkat seiring pertumbunan penduduk dan laju ekonomi. Masyarakat adalah pihak yang paling signifikan apabila terjadi krisis. Masukan dari masyarakat menjadi faktor yang dianggap utama dalam latar belakang penyusunan kebijakan antisipasi krisis energi.

Dalam information processing model of choice, sebuah kebijakan harus memperhatikan fenomena informasi yang sedang berkembang di kalangan para pemangku kepentingan. Pemangku kepentingan yang paling dasar dari masalah krisis energi adalah masyarakat secara luas. Fenomena komunikasi dari masyarakat menjadi faktor yang dianggap utama dalam latar belakang penyusunan kebijakan antisipasi krisis energi. Lembaga pemerintah yang terkait langsung maupun tidak langsung membicarakan energi dipahami dengan melihat pengalaman individu dalam memilih pertimbangan yang dijadikan dasar dari kebijakan terkait krisis energi. Kebijakan juga dipengaruhi oleh proses kognitif 
individu dan organisasi dalam menterjemahkan informasi terkait. Proses kognitif individu dan organisasi terbangun dari pengalaman mengolah pesan (komunikasi) berdasar pada rasionalisasi data dan informasi yang berasal dari dalam maupun luar organisasi.

Proses kognitif dalam pembuatan keputusan jika dikaitkan dengan sensemaking, merujuk pada aspek grounded in identity construction, menunjukkan bagaimana stakeholder berfikir dan mengolah data sebagai pertimbangan membuat kebijakan. Kebijakan antisipasi krisis energi, jika dilihat dari pengalaman individu sudah memenuhi aspek retrospective yang mana dalam membuat keputusan perlu proses refleksi dari pengalamanpengalaman komunikasi dengan pihak terkait dan mengolah data serta informasi. Data dan informasi mengenai nilai impor energi, ketersediaan, keseimbangan supply and demand serta masukan masyarakat adalah tanda (cues) yang merupakan dasar aspek focused on and by extracted cues dari sensemaking.

\section{Simpulan}

Solusi menuju konvergensi arah komunikasi kebijakan publik dalam rangka antisipasi krisis energi dibangun dengan atas dasar komunikasi organisasi dalam formulasi dan implementasi kebijakan publik menghadapi krisis energi. Komunikasi organisasi dipahami dengan mempelajari makna, kebijakan, dan pertimbangan dalam menyusun kebijakan krisis energi.

Krisis dipahami terbatas pada aspek ekonomi oleh para pembuat kebijakan. Faktanya krisis energi mencakup masalah lingkungan hidup. Isu pembangunan berkelanjutan yang memperhatikan lingkungan hidup tentang energi bersih dan keberlanjutan energi tidak menjadi pembicaraan. Kebijakan dalam usaha antisipasi krisis terbatas pada aspek penghematan energi (konservasi) dan pengembangan energi non fosil.

Sensemaking menjadi pertimbangan pada proses komunikasi organisasi dalam formulasi dan implementasi kebijakan publik menghadapi krisis energi. Dalam kajian ini tersirat bahwa terdapat beberapa sifat sensemaking antara lain ; grounded in identity construction, retrospective, enactive of sensible environment dan social. Faktanya dari 6 sifat positif sensemaking hanya 4 yang teridentifikasi sebagai dasar pembuatan kebijakan. Sosialisasi yang dijadikan alat untuk mendapatkan feedback dari masyarakat kurang bermakna karena tidak bisa mengukur adoptability masyarakat.

Dewan Energi Nasional (DEN) adalah sebuah lembaga yang bersifat hybrid dibentuk pemerintah. Komunikasi organisasi antara dari unsur pemerintah dan unsur pemangku kepentingan lintas sektoral di DEN faktanya belum mampu berjalan optimal. Pemaknaan (problem statement) dan kepentingan atas krisis energi yang belum sama menyebabkan komunikasi organisasi tidak berjalan optimal. Nilai (value) independensi organisasi yang hybrid merupakan solusi komunikasi organisasi yang optimal untuk membuat kebijakan antisipasi krisis energi yang melibatkan lintas sektoral dalam konteks krisis energi yang multi dimensi.

Krisis energi terbatas dimaknai sebagai masalah ekomomi saja. Lebih jauh sebenarnya krisis energi juga mengandung persoalan yang berkaitan dengan lingkungan hidup. Pemanfaatan energi fosil sekarang ini banyak sekali menimbulkan efek negatif pada sisi lingkungan hidup. Eksplorasi yang berlebihan menyebabkan krisis ekologi karena penurunan kondisi lingkungan yang cukup signifikan. Hasil pembakaran energi fosil menimbulkan dampak polusi, global warming yang berakibat pada perubahan iklim (climate change).

Dalam lingkup konseptual/teoritis, dengan menggunakan prinsip sensemaking, pembuat keputusan melihat respon/interpretasi terhadap lingkungan dan bagaimana persepsi itu membentuk kebijakan yang dipilih. Penelitian ini belum masuk pada bahasan struktur organisasi dan dimensi ekonomi politik antisipasi krisis energi. Dalam membuat kebijakan, struktur organisasi dapat dipahami sebagai faktor yang menentukan arah sebuah kebijakan. Struktur 
merupakan refleksi dari kuasa atas informasi dalam membuat keputusan. Pada aspek ekonomi politik, energi secara makro berkaitan erat dengan faktor ekonomi yang dipengaruhi juga oleh kondisi politik.

Hasil penelitian ini dapat ditindaklanjuti dengan menggunakan perspektif yang berbeda. Perspektif konstruktivist dengan gagasan fenomenologi pada penelitian ini lebih mengedepankan aspek eksistensial dari masingmasing individu pada sebuah lembaga. Kajian lebih lanjut misalnya, dapat menggunakan perspektif kritis dengan gagasan strukturasi atau ekonomi politik yang melihat aspek relasi kekuasaan berdasar struktur diantara lembagalembaga yang menyusun kebijakan antisipasi krisis energi.

Pada tataran metodologis, penelitian ini menggunakan metoda kualitatif fenomenologi (konstruktivist). Studi selanjutnya dapat menggunakan metoda fenomenologi dengan tradisi kritis (inferensi etnografi kritis) yang digunakan untuk membedah strukturasi dan dimensi ekonomi politik. Pendekatan kritis bertujuan menggali faktor tersembunyi seperti bagaimana kekuasaan atau kekuatan dan hegemoni mempengaruhi suatu individu dalam lembaga serta berupaya membuka agendaagenda tersembunyi dibalik sebuah realitas organisasi.

\section{Daftar Pustaka}

Grossman P Z. (2015). Energy shocks, crises and the policy process: A review of theory and application. Energy Policy. 77:5669. doi:10.1016/j.enpol.2014.11.031

Jablin F M, Linda L P. (2001). The New Handbook of Organizational Communication, Advance in Theory, Research, and Methods, Thousand Oaks, (US) SAGE Publications Keamanan Nasional : Indonesia di Ambang Krisis Energi. (2015, Maret 5). Kompas hal 1 KeamananNasional:KetahananEnergi Indonesia Merosot. (2015, Maret 6). Kompas hal 1 Littlejohn SW, Foss KA. (2005). Theories of
Human Communication. $8^{\text {th }}$ edition. Belmont (US): Thomson Wadsworth Minichielo V, Aroni R, Timewell, Eric, Alexander L. (1995) In-depth Interviewing. $2^{\text {nd }}$ edition. Melbourne (AU): Longman. Moustakas C. (1994). Phenomenology Research Method. Thousand Oak (US) Sage Publication. Neuman, WL. (2006). Social Research Methods : Qualitative and Quantitative Approaches. $6^{\text {th }}$ edition. Boston (US): Pearson Peraturan Presiden Nomor 22 Tahun 2017 Tentang Rencana Umum Energi Nasional Peraturan Presiden No 41 Tahun 2016 Tentang Tata Cara Penetapan dan Penanggulangan Krisis Energi dan Darurat Energi Peraturan Pemerintah No 79 Tahun 2014 Tentang Kebijakan Energi Nasional, Quarry W. Ramirez R. (2009). Communication for Another Development: Listening before Telling, London (GB) Zed Books

Rezavidi Arya (2012) Membaca Nasib Energi Baru dan Terbarukan di Indonesia [Internet] http://www.meti.or.id/ subpage.php?page $=6 \&$ mode $=$ content $\&$ idcontent $=132 \&$ judul $=$ Membaca $\% 20$ Nasib\%20Energi\%20Baru\%20dan\%20 Terbarukan\%20di\%20Indonesia. html\&lang=idDiaksestanggal8Juni2015

Rogers, E M. (2003). Diffusion of Innovations. New York (US): Free Pr. Seligman, L. (2006). Sensemaking throughout adoption and the innovation-decision process. European J Innovation Management. 9(1):108-120. doi: $10.1108 / 14601060610640050$

Starbuck W, Milliken F. (1988). Executive perceptual filters: What they notice and how they make sense. in D. Hambrick (ed.) The executive effect: Concepts and methods for studying top managers. Greenwich (GB): JAI Press. Tenaga Nuklir,PLTNDinilaiAncamKemandirian. (2015, Mei 24), Kompas hal 14 Trujillo, N., \& Toth, E. (1987). Organisational perspectives for public relations 
research and practice. Management Communication Quarter, 1(2), 199-231 .doi: $\quad 10.1177 / 0893318987001002004$

Undang-Undang Nomor $30 \quad$ Tahun

2007 Tentang Energi

Weick KE.1995. Sensemaking in organizations. Thousand Oak (US) Sage Publications. 